\title{
Microbiology Water Quality of Three Coastal Beaches at Madeira Island, Atlantic Ocean
}

\author{
Costaa $\mathbf{G}^{1^{*}}$, Caladob $\mathbf{G}^{2}$, Errab $\mathrm{F}^{2}$, Freitasa $\mathbf{M}^{1}$, Krehla $\mathbf{K}^{1}$ and Pinheiro de Carvalhoc MAA ${ }^{3}$ \\ ${ }^{1}$ Marine Biological Station, University of Madeira, Funchal Promenade Sea Front, 9000-107 Funchal, Madeira, Portugal \\ ${ }^{2}$ Public Health Laboratory, Seminary Street, 9050-022, Funchal, Portugal \\ 3/SOPLexis, University of Madeira, Campus Penteada, 9000-390 Funchal, Madeira, Portugal
}

*Corresponding author: Costaa G, Marine Biological Station, University of Madeira, Funchal Promenade Sea Front, 9000-107 Funchal, Madeira, Portugal, Tel: +351291700360; E-mail: gcosta@uma.pt

Rec date: Apr 15, 2014, Acc date: Jul 26, 2014, Pub date: Aug 06, 2014

Copyright: (C) 2014 Costaa G, et al. This is an open-access article distributed under the terms of the Creative Commons Attribution License, which permits unrestricted use, distribution, and reproduction in any medium, provided the original author and source are credited.

\begin{abstract}
The microbial water quality of three different coastal beaches located in the south coast of Madeira Island, were monitored from May to December 2005 (Formosa and São Roque), and from October 2006 to June 2007 (Gavinas). Total and fecal coliforms and enterococci counts in two of the beach sites, showed a seasonal dependence, with highest values in autumn and winter suggesting a positive relationship with rainfall and a negative relationship with temperature. Of the three sampled beaches, Formosa beach showed the highest water quality and São Roque beach the poorest water quality. Impacted freshwater discharges and deficient water circulation in this recreational zone could be the causes for the lower quality of this beach. However beach rating was shown to be dependent on the indicator microbe chosen. The results obtained emphasized the need of differential sampling strategies according to beach specific characteristics, when assessing the water quality, as well as further sampling taking into consideration other variables, such as time of the day, tide, and microbial analysis of the freshwater inputs.
\end{abstract}

Keywords: Enterococci; Fecal coliforms, Madeira Island; Microbial indicators; Water quality

\section{Introduction}

Coastal marine environments are highly vulnerable to anthropogenic pollution from municipal sewage, industrial effluents as well as agriculture run-off and river discharges [1-3]. Fecal contamination not only impairs water quality but also potentiates human health risks [4,5]. In urbanized areas, possibly sources of fecal pollution can include deficient sewage treatment and leaks due to wastewater treatment plant outflows [3,6,7]. Many coastal beaches are located near urban areas, others near river discharges, with input from agricultural and industrial wastes, so that potential risks of contamination may exist, whenever sewage treatment is not effective $[1,8]$. Therefore regular monitoring of the quality of coastal waters has been suggested $[9,10]$, employing different sampling strategies, according to the specific characteristics of the recreational area in terms of physical-chemical parameters and number of bathers [11,12]. Two European directives recommended the microbial parameters to be taken into consideration, when assessing the quality of bathing waters (76/160/EEC and 2006/7/EEC). These directives are being followed by member states in order to determine the quality of their bathing waters, and investigate potential health risks associated with fecal polluted waters. Madeira Island, located in the Macaronesian Biogeographic Region, is a popular touristic destination for many European and non-European countries, with a coastline composed of several beaches and sea resorts, highly appreciated for its round the year water warm temperatures from 18 up to $23^{\circ} \mathrm{C}$. Bathers, due to the warm weather conditions, attend beaches almost all year, including in autumn and winter, when water quality monitoring is not done by official mandate institutions. The aim of the present study was to evaluate the microbiological quality of coastal waters in three different beaches in the south coast of Madeira, located near populated areas, in different times of the year, based on the total and fecal coliform counts, as well as on the fecal enterococci. The influence of environmental parameters on the indicator values and their significance for the evaluation of the quality of waters is discussed.

\section{Methods}

\section{Sampling collection and sampling site characterization}

Sampling sites were located in three different points at the south coast of Madeira Island, located in Central North Atlantic Ocean $\left(33^{\circ} 7^{\prime} 30^{\prime \prime}-32^{\circ} 22^{\prime} 20^{\prime \prime} \mathrm{N}\right.$ and $16^{\circ} 16^{\prime} 30^{\prime}-17^{\circ} 16^{\prime} 38^{\prime \prime} \mathrm{W}$ ) (Figure 1). Surface water samples, at 1 meter depth, were collected at all sites during the morning, using sterile $500 \mathrm{ml}$ bottles. Sampling in Formosa (Funchal) and São Roque (Machico) beaches was done from May to December 2005, twice a month, except for May when 3 samples were taken. Sampling in Gavinas (Lido) beach was conducted from October 2006 to June 2007. Seventeen water samples were collected from both beaches Formosa and São Roque. From Gavinas beach, 9 water samples were collected from October 2006 to June 2007. Formosa is an open sea beach with about $1 \mathrm{~km}$ in extension, São Roque beach is limited by two piers and with a total extension of 330 meters, while Gavinas beach, is a smaller bay with 80 meters in total length. All beaches are predominantly pebble and rocky with just a few sandy patches. Air and water temperature as well as rainfall data were either recorded on site or obtained from the Regional Meteorological Institute. Water conductivity was measured with a probe meter. Turbidity was measured as NTUs. At the laboratory the water $\mathrm{pH}$ was measured with a $\mathrm{pH}$ meter. 


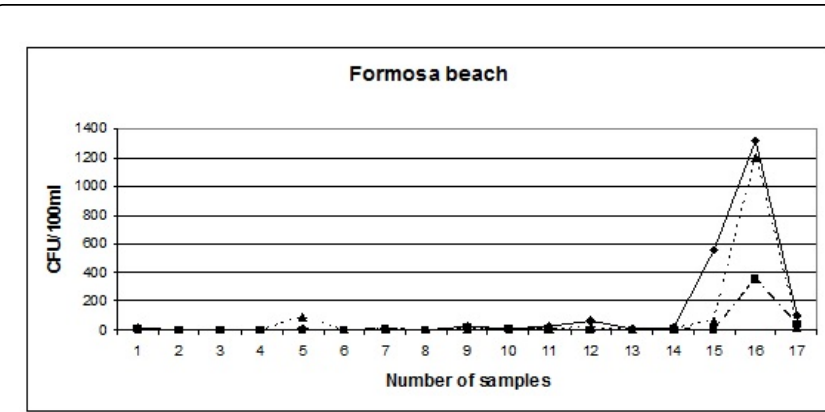

(A)

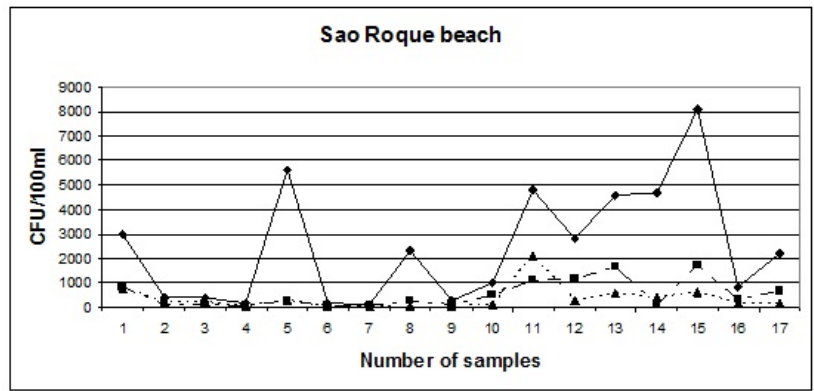

(B)

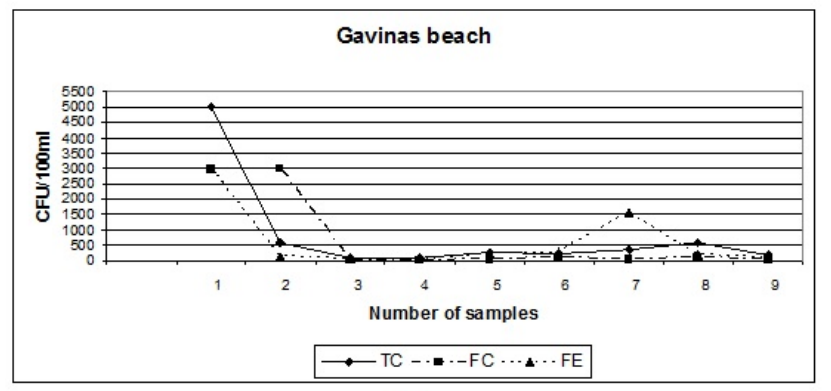

(c)

Figure 1: Map of Madeira Island with indication of the three sampled marine beaches, Formosa (A) Gavinas (B) and São Roque, Machico (C).

\section{Determination of microbial parameters}

Total coliform (TC), fecal coliform (FC) and fecal enterococci (FE) counts were enumerated using the membrane filtration method (MF). Water samples $(10-100 \mathrm{ml})$ were filtered through $0.45 \mu \mathrm{m}$ membrane filters (Pall Corporation) and filters transferred to membrane lauryl sulphate agar (OXOID), mFC agar (DIFCO) and either KF Streptococcus agar or Slanetz Bartley agar (OXOID). Plates were incubated at $35-37^{\circ} \mathrm{C}$ for $\mathrm{TC}$ and $\mathrm{FE}$, while for $\mathrm{FC}$ plates were incubated at $44^{\circ} \mathrm{C}$ for $24-48 \mathrm{hr}$. After that period, filters with red colonies in KF Streptococcus agar or Slanetz Bartley agar, were transferred to bile aesculin azide agar (OXOID) for confirmation. Dark brown colonies were considered positive. Positive colonies in membrane lauryl sulphate agar (yellow) were submitted to the oxidase test (OXOID), inoculated in Kliger iron agar (OXOID) and identified with the strips API 20E (Biomérieux). Dark blue colonies in mFC agar were counted as fecal coliforms.

\section{Statistical analysis}

Water samples of Gavinas beach were taken monthly in triplicate and numbers of indicator bacteria were averaged to obtain a single value, whereas in Formosa and São Roque beaches single water samples were taken twice a month. The correlation between the indicator parameters and the environmental variables were examined using the Spearman's correlation coefficient. For the estimation of mean abundances and the $95 \%$ confidence intervals of total and fecal coliforms and fecal enterococci, data were log transformed [13]. All statistical analysis was performed with SPSS 11.0.

\section{Results}

The two coastal beaches, Formosa and São Roque were characterized by a constant salinity of $35 \%$ and $\mathrm{pH}=8.2$. Water temperature varied from 18.0 to $22.5^{\circ} \mathrm{C}$ in Formosa, and 18.5 to $23.5^{\circ} \mathrm{C}$ in São Roque. Waters of both beaches did not show presence of mineral oils and suspended solids, no abnormal odors and were transparent in appearance. In Gavinas beach the water temperature varied from 17.5 to $21.5^{\circ} \mathrm{C}$, $\mathrm{pH}$ was 8.0 , and salinity was also $35 \%$. During the sampling period, in both beaches Formosa and São Roque, from May 2005 to December 2006, only in December substantial rainfall occurred $(63 \mathrm{~mm} /$ day $)$ and some rainfall occurred in September $(4.1 \mathrm{~mm} /$ day), while during the remaining of sampling periods no rainfall or negligible rainfall less than $0.5 \mathrm{~mm} /$ day occurred. From October 2006 to June 2007, (sampling in Gavinas beach) rainfall was less than $0.5 \mathrm{~mm} /$ day except in March and April when $7.7 \mathrm{~mm}$ and $3.3 \mathrm{~mm}$ /day were registered. Monthly variations in numbers of the indicator parameters were found in all beaches, with higher values observed in São Roque beach (Figure 2). The highest values for TC, FC and FE for Formosa were found in December (1315, 352 and $1199 \mathrm{cfu} / 100 \mathrm{ml}$ respectively). In the other months of the year values were below the EU guide value of $500 \mathrm{cfu} / 100 \mathrm{ml}$ for TC and 100 $\mathrm{cfu} / 100 \mathrm{ml}$ for FC and FE. In this beach only 2 samples exceeded the recommended limits of $500 \mathrm{cfu} / 100 \mathrm{ml}$ for TC, so that a percentage of compliance of $88 \%$ was obtained. Regarding the FC and FE counts only one sample was above the guide limit of $100 \mathrm{cfu} / 100 \mathrm{ml}$ for these parameters. São Roque showed higher values of the indicator parameters, well above the guide values, in several occasions (Figure 2). Although these values did not surpass the maximum allowed value of $10,000 \mathrm{cfu} / \mathrm{ml}$ for TC, and $2000 \mathrm{cfu} / \mathrm{ml}$ for FC, they were above the guide limits for TC and FC counts, 11 times and 13 times respectively. Identically the values of fecal enterococci in this site were above the limit of $100 \mathrm{cfu} / 100 \mathrm{ml}$ in 11 of the 17 water samples. In Gavinas beach, for the parameter TC, 6 out of 9 samples had values above the guide limit. Furthermore the TC and FC values in October and November 2006, were too numerous to be accurately counted. The fecal coliform counts (FC) were above the guide limit in 3 of the water samples and the fecal enterococci values (FE) were 5 times above the guide limit (Figure 2). The mean values of the three indicator parameters and their $95 \%$ confidence intervals are shown on Table 1 . Based on the values of the indicator parameters, beach Formosa were rated as excellent for all three parameters, São Roque was rated as poor for FC and FE and moderate considering the TC counts, and Gavinas beach was cautiously classified as moderate for TC and FC, but poor in relation to FE counts. Positive and significant correlations were found between the indicator parameters in the three beaches (Table 2). The response of indicator bacteria to the environmental parameters (temperature, turbidity and rainfall) was variable, with higher values in winter at Formosa beach, higher values in autumn and spring at 
Gavinas beach, whereas in São Roque beach fluctuations occurred all through the sampling period, with higher values of the indicator parameters obtained in winter (Figure 2). For Formosa and São Roque beaches, positive and significant correlations were found between total coliform and fecal enterococci densities, with rainfall and turbidity (Table 2). The influence of temperature on indicator microbes, although showing a negative correlation, was not significant in all occasions as seen in Table 2. Accordingly, total coliforms decreased with increasing temperatures in both beaches, whereas fecal coliforms and enterococci decreased with increasing temperatures only in São Roque beach. In Gavinas beach no significant correlations were found between either rainfall or temperature, with the indicator microbes. Rainfall and turbidity were the variables, with greater effect on densities of indicator bacteria in Formosa and São Roque beaches. Nevertheless the significance of correlation values in São Roque beach and the high counts of indicator microbes found in both wet and dry seasons, suggests that other factors can influence the densities of indicator bacteria. Likewise in Gavinas beach, water quality did not seem to be influenced solely by rainfall, as high microbe counts were found in the dry and wet periods. The identification of the bacteria to species level in Formosa beach demonstrated a predominance of Escherichia coli (45\%), followed by Enterococcus faecium (28.9\%), Klebsiella pneumoniae (14.1\%), Klebsiella oxytoca (5.2\%), Enterobacter cloacae (5.3\%) and Enterococcus faecalis (1.26\%). In São Roque beach Klebsiella spp. occurred in higher percentage (28.6\%), followed by Enterobacter cloacae (28.5\%), E. coli (11.2\%), Aeromonas spp (15.9\%), Klebsiella pneumoniae (9.9\%), E. faecalis (2.5\%), E. faecium $(0.93 \%)$ and E. gallinarum $(0.86 \%)$.

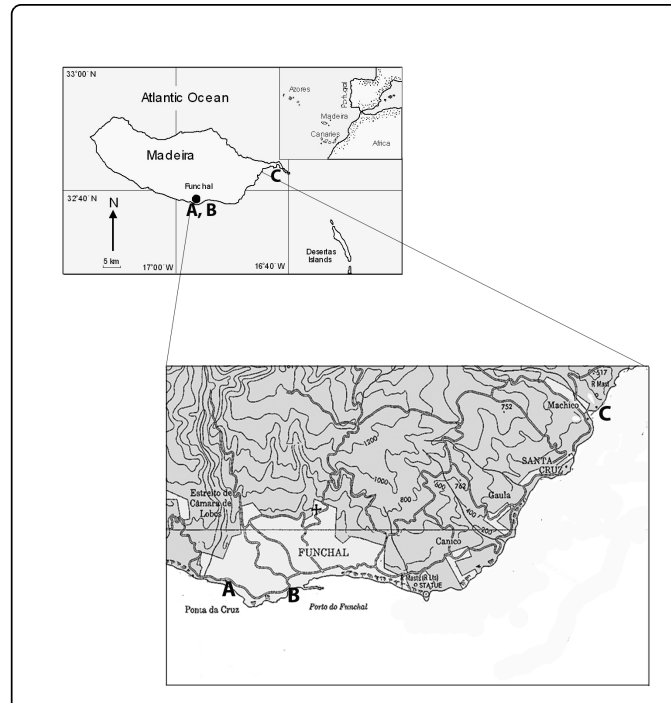

Figure 2: Distribution of total coliforms (TC), fecal coliforms (FC) and fecal enterocci (FE) in three different marine beaches at the south coast of Madeira Island, along the year.

\begin{tabular}{|l|l|l|l|l|}
\hline Parameter & Beach & Mean $(95 \% \mathrm{Cl})$ & Min-Max. & Rating \\
\hline Total & Formosa & $128.41(47.91-344.14)$ & $(0-1315)$ & Excellent \\
\hline coliform & São Roque & $2439.65(1167.3-5098.87)$ & $(104-8100)$ & Moderate \\
\hline counts (TC) & Gavinas & $294.75(161.95-536.40)^{*}$ & $(87-580)$ & Moderate \\
\hline Fecal & Formosa & $27.12(12.85-57.22)$ & $(0-352)$ & Excellent \\
\hline coliforms & São Roque & $536.53(286.91-1003.3)$ & $(39-1710)$ & Poor \\
\hline$($ FC) & Gavinas & $32.14(16.48-62.67)^{\star}$ & $(10-75)$ & Excellent \\
\hline Fecal & Formosa & $84.88(33.29-216.44)$ & $(0-1199)$ & Excellent \\
\hline Enterococci & São Roque & $358.06(188.75-679.24)$ & $(14-2080)$ & Poor \\
\hline$($ FE) & Gavinas & $315.00(76.46-1297.8)^{\star}$ & $(7-1587)$ & Poor \\
\hline
\end{tabular}

Table 1: Abundance of total coliforms (TC), fecal coliforms (FC) and fecal enterococci (FE) in three different beaches in the south coast of Madeira Island, and beach rating according to bacteriological indicators.

\section{Discussion}

An increased risk for the transmission of waterborne diseases may exist in waters with high levels of indicator bacteria, which are associated with fecal contamination $[4,10,14,15]$. Our results showed that the levels of indicator bacteria in the recreational waters sampled were highly variable between beaches and with the time of the year (Figure 2 and Tables 1 and 2). The high levels of indicator bacteria found in December 2005 in Formosa beach could be due to the intense rainfall that occurred at that time, and the consequent input of run-off from land. This however was not the only factor affecting the water quality of São Roque beach, where the levels of indicator bacteria were above regulatory limits in several occasions, with and without rainfall (Figure 2). The topography of this beach might cause poor water exchange with a consequent decrease in water quality. Nevertheless a significant effect of rainfall on the indicator bacteria levels was found in this beach (Table 2). During rainfall events not only water turbidity might increase due to input of particulate matter from freshwater sources, but also the intense rainfall might lead to an input of untreated sewage into the sea and a consequent rise in indicator bacteria $[6,8,16]$. Turbidity has shown to influence the coliform levels due to re-suspension of sediment-bound bacteria [17]. Rainfall and storm events are implicated also in re-suspension of bacteria and might explain the high densities observed in December 2006 in 
Formosa and in April 2007 in Gavinas beach [17-19]. Additionally in temperate-tropical regions, such as Madeira Island, the persistence and re-growth of indicator microbes can contribute to an increase in their numbers [10]. Nevertheless temperature was in some occasions significantly negatively correlated with indicator bacterial levels. In fact increasing temperatures are associated with higher solar radiation exposure, which was proved to affect the survival of indicator bacteria $[6,8,10,20,21]$. Although no measurements of the levels of solar radiation were done in the present study, our data implied that densities of indicator bacteria for Formosa and Gavinas were generally lower in spring and summer. This, combined with the negative correlation between temperature and indicator bacteria counts, suggested indeed a sensitivity of bacteria to solar radiation, with total coliforms and fecal coliforms been mostly affected, whereas fecal enterococci were less sensitive to solar radiation (Table 2). A number of studies demonstrated that Enterococci were the group with higher resistance to environmental stress [21,22-25]. They may therefore be more suitable as indicators of fecal contamination due to their higher survival in water and their inability of multiplying in polluted waters [26]. The bacterial species found in Formosa and São Roque beaches, suggested fecal and non-fecal pollution, as the identified bacteria are common in the intestines of humans and other animals as well as in the environment. In São Roque beach the relative high percentage of Aeromonas spp (15.9\%) could denote an input of freshwater and sewage into this beach $[9,27]$. In order to determine the real source of these microorganisms, whether they were from human fecal origin, environment or feces of other animals, specific techniques such as ribotyping have been recommended [9] or the choice of alternative indicators such as coliphages [28]. Even so no indicator so far chosen, proved to be perfect for microbial water quality characterization, so that when assessing the quality of waters one has to balance costs, speed and effectiveness of results [3,29]. It is also important to increase the sampling effort, with collection of waters samples in different times of the day, to have a clear picture of the water quality of a given water course, as bacterial counts may change from morning to afternoon due to tidal circulation $[12,30]$.

\begin{tabular}{|c|c|c|c|c|c|c|}
\hline Parameter & Rainfall & Temperature & Turbidity & TC & FC & FE \\
\hline Rain & 1.000 & & & & & \\
\hline \multirow[b]{3}{*}{ Temp } & $-0.292 ; p=0.128(A)$ & 1.000 & & & & \\
\hline & $-0.156 ; p=0.688(B)$ & & & & & \\
\hline & $-0.425 ; p=0.045(C)$ & & & & & \\
\hline \multirow[b]{3}{*}{ Turbidity } & $0.617 ; p=0.004(A)$ & $-0.498 ; p=0.021(A)$ & 1.000 & & & \\
\hline & - & - & & & & \\
\hline & $0.616 ; p=0.004(C)$ & $-0.567 ; p=0.009(C)$ & & & & \\
\hline \multirow[b]{3}{*}{ TC } & $0.609 ; p=0.005(A)$ & $-0.516 ; p=0.017(A)$ & $0.664 ; p=0.002(A)$ & 1.000 & & \\
\hline & $0.110 ; p=0.779(B)$ & $0.479 ; p=0.192(B)$ & - & & & \\
\hline & $0.447 ; p=0.036(C)$ & $-0.410 ; p=0.051(C)$ & $0.422 ; p=0.046(C)$ & & & \\
\hline \multirow[b]{3}{*}{ FC } & $0.282 ; p=0.136(A)$ & $-0.182 ; p=0.242(A)$ & $0.357 ; p=0.080(A)$ & $0.768 ; p=0.000(A)$ & & \\
\hline & $0.350 ; p=0.356(B)$ & $0.386 ; p=0.305(B)$ & - & $0.790 ; p=0.010(B)$ & & \\
\hline & $0.661, p=0.002(C)$ & $-0.588 ; p=0.007(C)$ & $0.627 ; p=0.004(C)$ & $0.799 ; p=0.000(C)$ & 1.000 & \\
\hline \multirow[b]{3}{*}{$\mathrm{FE}$} & $0.489 ; p=0.023(A)$ & $-0.212 ; p=0.207(A)$ & $0.450 ; p=0.035(A)$ & $0.733 ; p=0.001(A)$ & $0.618 ; p=0.008(A)$ & 1.000 \\
\hline & $0.621 ; p=0.074(B)$ & $0.034 ; p=0.932(B)$ & - & $0.733 ; p=0.025(B)$ & $0.723 ; p=0.028(B)$ & \\
\hline & $0.512 ; p=0.018(C)$ & $-0.549 ; p=0.011(C)$ & $0.396 ; p=0.058(C)$ & $0.856 ; p=0.000(C)$ & $0.768 ; p=0.000(C)$ & \\
\hline
\end{tabular}

Table 2: Correlations (rs) between physico-chemical parameters and indicator bacteria at the three beach sites. Beaches are indicated as (A) Formosa, (B) Gavinas and (C) São Roque:

\section{Conclusions}

The results obtained suggested that the quality of the recreational waters, examined in this study, can be strongly influenced by rainfall and consequent increase in water turbidity, during autumn and winter months. Given the variability in the water quality in the three beaches monitored, specifically in Gavinas and São Roque beaches, with poor water quality in several occasions, further studies are recommended with an increased periodicity of sampling, and the inclusion of additional variables, such as time of the day and tidal regime, as well as an assessment of the quality and quantity of freshwater input into those beaches.

\section{Acknowledgments}

Financial support for the present research was provided by the Department of Public Health of Funchal, Madeira Government (IPRAM) and Foundation of Science and Technology (FCT). We are 
grateful to the Institute of Metereology of Funchal for the data on water temperature and rainfall.

\section{References}

1. Kay D, Wyer MD, Crowther J, Fewtrell L (1999) Faecal indicator impacts in recreational waters: budget studies and diffuse source modeling. J Appl Microbiol, Symposium Supplement 85: 70S-82S.

2. Kamizoulis G, Saliba L (2004) Development of coastal recreational water quality standards in the Mediterranean. Environ Int 30: 841-854.

3. Wilkes G, Edge T, Gannon V, Jokinen C, Lyautey E et al. (2009) Seasonal relationships among indicator bacteria, pathogenic bacteria, Cryptosporidium oocysts, Giardia oocysts, and hydrological indices for surface waters within and agricultural landscape. Water Res 43: 2209-2223.

4. Kay D, Fleisher JM, Godfree AF, Jones F, Salmon RL et al. (1994) Predicting the likelihood of gastero-enteritis from sea bathing: results from randomized exposure. Lancet 344: 905-909.

5. Fleisher JM, Kay D, Wyer MD, Godfree AF (1998) Estimates of the severity of illnesses associated with bathing in marine recreational waters contaminated with domestic sewage. Int J Epidemiol 27: 722-726.

6. Mill A, Schlacher T, Katouli M (2006) Tidal and longitudinal variation of faecal indicator bacteria in an estuarine creek in south-east Queensland, Australia. Mar Pollut Bull 52: 881-891.

7. Walters SP, Thebo AL, Boehm AB (2011) Impact of urbanization and agriculture on the occurrence of bacterial pathogens and stx genes in coastal waterbodies of central California. Water Res 45: 1752-1762.

8. Crowther J, Kay D, Wyer MD (2001) Relationships between microbial water quality and environmental conditions in coastal recreational waters: The Fylde coast, UK. Water Res 35: 4029-4038.

9. Wheeler AL, Hartel PG, Godfrey DG, Hill JL, Segars WI (2002) Potential of Enterococcus faecalis as human fecal indicator for microbial source tracking. J Environ Qual 31: 1286-1293.

10. Shibata T, Solo-Gabriele HM, Fleming LE, Elmir S (2004) Monitoring marine recreational water quality using multiple microbial indicators in an urban tropical environment. Water Res 38: 3119-3131.

11. Efstratiou MA (2001) Managing coastal bathing water quality: The contribution of microbiology and epidemiology. Mar Pollut Bull 42: 425-431.

12. Bordalo AA (2003) Microbiological water quality in urban coastal beaches: the influence of water dynamics and optimization of the sampling strategy. Water Res 37: 3233-3241.

13. Fowler J, Cohen L, Jarvis P (1998) Practical Statistics for Field Biology John Wiley \& Sons, Chichester, UK.

14. Cabelli VJ, Dufour AP, McCabe LJ, Levin MA (1982) Swimming associated gastroenteritis and water quality. Am J Epidemiol 115: 606-616.

15. Bonilla TD, Nowosielski K, Cuvelier M, Hartz A, Green M et al. (2007) Prevalence and distribution of fecal indicator organisms in South Florida beach sand and preliminary assessment of health effects associated with beach sand exposure. Mar Pollut Bull 54: 1472-1482.

16. Chigbu P, Gordon S, Strange $\mathrm{T}$ (2004) Influence of inter-annual variations in climatic factors on fecal coliform levels in Mississippi Sound. Water Res 38: 4341-4352.

17. Jamieson RC, Joy DM, Lee H, Kostaschuk R, Gordon RJ (2005) Resuspension of sediment-associated Escherichia coli in a natural stream. J Environ Qual 34: 581-590.

18. Davies CM, Long JAH, Donald M, Ashbolt NJ (1995) Survival of fecal microorganisms in marine and freshwater sediments. Appl Environ Microbiol 61: 1888-1896.

19. Solo-Gabriele HM, Wolfert MA, Desmarais TR, Palmer CJ (2000) Sources of Escherichia coli in a coastal subtropical environment. Appl Environ Microbiol 66: 230-237.

20. Davies-Colley RJ, Bell RG, Donnison AM (1994) Sunlight inactivation of enterococci and faecal coliforms in sewage effluent diluted in seawater. Appl Environ Microbiol 60: 2049-2058.

21. Rozen Y, Belkin S (2001) Survival of enteric bacteria in seawater. FEMS Microbiol Rev 25: 513-529.

22. Solic M, Krstulovic N (1992) Separate and combined effects of solar radiation, temperature, salinity and $\mathrm{pH}$ on the survival of faecal coliforms in sea water. Mar Pollut Bull 24: 411-416.

23. Lleò MM, Bonato B, Tafi MC, Signoretto C, Boaretti M et al. (2001) Ressuscitation rate in different enterococcal species in the viable but nonculturable state. J Appl Microbiol 91: 1095-1102.

24. Noble RT, Lee IM, Schiff KC (2004) Inactivation of indicator microorganisms from various sources of fecal contamination in seawater and freshwater. J Appl Microbiol 96: 464-472.

25. Whitman RL, Nevers MB (2008) Summer E. coli patterns and responses along 23 hicago beaches. Environ Sci \& Technol 42: 9217-9224.

26. Jin G, Englande AJ, Bradford H, Jeng H (2004) Comparison of E. coli, enterococci and fecal coliform as indicators for brackish water quality assessment. Wat Environ Res 76: 245-255.

27. Holt JG, Krieg NR, Sneath PHA, Staley JT, Williams ST (1994) Bergey's Manual of Determinative Bacteriology. Lippincott Williams \& Wilkins, London, UK.

28. Janelidze N, Jaiani E, Lashkhi N, Tskhvediani A, Kokashvili T et al. (2011) Microbial water quality of the Georgian coastal zone of the Black Sea. Mar Pollut Bull 62: 573-580.

29. Wade TJ, Calderon RL, Sams E, Beach M, Brenner KP et al. (2006) Rapidly measured indicators of recreational water quality are predictive of swimming-associated gastrointestinal illness. Environ Health Perspectives 114: 24-28.

30. Obiri-Danso K, Jones K, Paul N (1999) The effect of the time of sampling on compliance of bathing water in NW England with the EU Directive on bathing water quality. J Coastal Conserv 5: 51-58. 